\title{
A SMALL AUREI DEPOSIT FOUND IN RĂCARI FORT
}

\begin{abstract}
Four gold coins were found during the 2008 excavations in the Roman fort at Răcari (Oltenia), in latus dextrum, allegedly used as praetorium. As they were minted in the time of Vespasian, the fact could cast doubts for the chronology of the first phase of the fort, as stated before.

The paper is resuming the basics known about the phases of the fortification and their date, giving some details about the conditions of the discovery. The coins themselves are depicted as they were before cleaning, but missing a proper catalogue, as the numismatist left the publication project.

The work is concluded by some commentaries about the type of the enclosure of the first phase, compared with the most common traits of a marching camp, as well as some historical remarks, as, for instance, the value of that lost deposit.
\end{abstract}

Keywords: aurei, archaeological diggings, temporary camps, permanent military bases, military payments.

\section{INTRODUCTION}

$\mathbf{I}$ n the summer campaign of 2008 carried out at the Roman fort from Răcari (commune Brădeşti, Dolj County) was discovered a small deposit of aurei. The find was publicly announced quickly, in the same autumn, in a symposium held in Curtea de Argeş. The presentation was performed by the discoverers (Eugen S. Teodor and Corina Nicolae) and a numismatist specialised in Roman mints, Delia Moisil. All the three were colleagues at the History National Museum from Bucharest. Since then the deposit is expecting the publication.

In 2011 I lost the right of excavating in Răcari, due to my friends in the County Museum Dolj, and the subject was put on a long rest. About two years ago I have retaken the project of publication for this deposit, forced mainly by an unexpected miss-interpretation given by a leading historian. ${ }^{1}$ The first dead-line was proposed - and accepted by Delia Moisil - for March 2018. A sketch of the paper was done, more or less, on the target, but then we have realised that the deposit has to be put on a broader context of the gold coins lost during the Dacian wars. A long study was added here, concerning all discoveries from Roman Dacia which could concern coins related to a war time context. That second part was broadly ready in June 2018. Since then we are stuck, unable to finish the task, from reasons I can only suppose, but I do not know. As other three or four dead-lines passed without an effect, I have decided near the end of 2019 to publish my part as it is, with this short introduction, adding also some short commentaries at the end.

Of course, such a discovery - an aurei deposit found in a systematic excavation in a Roman fort, which is unique in Romania - would preferably

\section{Eugen S. TEODOR}

Romanian National History Museum, Bucharest esteo60@yahoo.co.uk

DOI: $10.14795 /$ j.v7i1.469

ISSN $2360-266 \mathrm{X}$

ISSN-L 2360 - 266X

\footnotetext{
PETOLESCU 2010, 104.
} 
offer both an archaeological rendition of the conditions of discovery, a numismatic catalogue and a numismatist point of view. Painfully, this proved impossible.

I will not take advantage of the research Delia Moisil made, although I know both the factual data and the main issues of discontent. The catalogue rebuilding will be not a problem for numismatists, as the pictures I will provide - although taken before cleaning - are very clear. Unfortunately, the study of the gold coins lost in the war time seems now compromised, although the results were very interesting. This is the real failure I was trying to avoid, delaying the publication. It happened nevertheless.

\section{GENERAL FACTS ABOUT THE FORT}

The digging campaign from the summer 2008 brought an unexpected discovery: a deposit of four aurei minted in the time of Vespasianus. Tempting to untie all the meanings of this collection of artefacts, I will start by describing the overall archaeological situation from the site.

The Roman fort from Răcari (Răcarii de Jos village, Brădeşti commune, Dolj County) is located in the very middle Oltenia, Romanian province located between Danube, Southern Carpathian Mountains and Olt River, being $29 \mathrm{~km}$ away from Craiova City, to northwest, and $6 \mathrm{~km}$ southeast from the town of Filiaşi. The fortification stands on the first left terrace of the Jiu River, today almost $2 \mathrm{~km}$ from the riverbed. The large floodable plain, located only $130 \mathrm{~m}$ away from the circuit wall, allows yet the hypothesis that in antiquity the fort was closely controlling the ford, one of the few on the middle and lower stream course. Jiu is a major river, splitting Oltenia in two halves, a western and an eastern one. The ford near Răcari is bridging these two halves. It is also the only Roman fort in central Oltenia, therefore a hub of communication.

The antique monument came early into the archaeologists' attention. The first systematic diggings took place in 1897-98, under the leadership of Grigore Tocilescu, ${ }^{2}$ the head of the Institute of Archaeology from Bucharest, ${ }^{3}$ the first and the only one in Romania that time. After three decades came next Grigore Florescu, excavating in the summers from 1928 and $1930 .^{4}$ Six decades later came on the site the next team, led by Cristian Vlădescu, also for a two years research, 1991-92. At last, the research has been resumed in 2003-2010, performed by a team under the coordination of Eugen S. Teodor.

The overall plan is sketched into the Figure 1. All stone buildings - principia, horreum, the gates, the towers and the curtain - are known before the Second World War. Cristian Vlădescu made two long cross trenches (S.1/1991 and S.2/1991) meeting in praetentura dextra, not finished and poorly reported, with only one published drawing for the stratigraphy of the western defences. The field research of the new team, since 2003, was meant first to understand

\footnotetext{
2 Though effectively performed in the field by Pamfil Polonic. The results were very briefly reported by TOCILESCU (1900, 136-140), dealing only with epigraphs and illustrating parts from two imperial bronze statues. Dumitru TUDOR (1965) made a more comprehensive presentation of the results of Polonic's diggings, using the archives from the Library of the Academy.

3 Named at the time Muzeul Naţional de Antichităţi (National Museum of Antiques), but working effectively as a research institute.

${ }^{4}$ FLORESCU 1931
}

and describe the defensive system on the eastern, northern and southern curtains, and finally, in the last three years, it developed a more detailed research in latus dextrum, north of the Vlădescu's trench S.1.

Avoiding here unnecessary controversies with our forerunners, ${ }^{5}$ as they cannot fight back, our field research has defined four stages of evolution. ${ }^{6}$ The most striking features and the best known are those connected with the third phase, the large stone fortification, built probably in the first decade of the third century. ${ }^{7}$ Everywhere in the fort have been noticed two sub-phases of it, with the same layout, both ended in fire, first in the third decade of the III century, ${ }^{8}$ the next within the Carpi invasion (around 245). ${ }^{9}$ The stone fort was erected following the external layout of a previous fort (second phase), made of timber, accomplished in the time of the Marcomannic Wars (168-180), replacing the former palisade with stone, but the details of the defensive system (for example the ditches) and the inner lay-out are to some extend different. That second fort from Răcari perished itself in flames, as documented on the northern and southern palisades, as well in some internal areas (as horreum). After the Carpi invasion the fort is not abandoned, but dramatic changes took place inside, not fully understood, as erecting new defensive walls (or the fourth phase), with changed plan - as that found on the trench S.2/2004 (see Fig.1) - and a completely new relationship between the roads and the buildings, showing the down of the Late Empire.

Our special interest here refers to the first stage of fortification in Răcari, ${ }^{10}$ also made of timber, smaller than the later ones (see the green lines at the Fig. 1). The first to intersect the defensive ditch of the small fort was Vlădescu, in 1991, against the western curtain, but apparently he did not understand what he found. We have studied the pendant situation, near the eastern curtain, the only one where the first defensive ditch appeared on a distant position from the curtain stone, being located $12.5 \mathrm{~m}$ inside the later. Finally, in 2006 there have been established the routes of the northern and the southern ditches, both placed just behind the stone curtain. The dimensions of those ditches have variations, from 1.7 to $2.3 \mathrm{~m}$ in depth and from 5.5 to $7.7 \mathrm{~m}$ on width, the most impressive being the southern one. The rampart of this first fort was completely removed when the large fort had to be set up, the old ditch being filled back. That removed rampart is considered to be similar in size with the ditches

\footnotetext{
See yet TUDOR 1965 for the previous understanding of the fort chronology. 6 TEODOR 2009 for a developed account of the defensive system, retaken here only sketchy.

In the largest forts from Oltenia, as Slăveni and Bumbești, have been built almost in the same time, revealing a strategic decision. The date of the new stone precinct walls for Slăveni and Bumbeşti is provided by epigraphic monuments: Slăveni (205 AD): IDR II 496-497 = CIL III 13801; Bumbeşti (201 AD): TUDOR 1978, 270; CIL III, 14475 a = ILS 9179 = IDR II 174 As for Răcari, an indirect late chronology is suggested by the funerary stele made for SVRA (IDR II, 164), found in the pavement of the left tower from porta praetoria, which is part of the third phase of building, as the stele itself couldn't be earlier than 160 AD. See also FLORESCU 1931, 18.

${ }^{8}$ A burned layer dating in the first half of the third century is mentioned in the notes (not published, but still kept at the Library of the Romanian Academy) made by Pamfil Polonic (TUDOR 1965, 237-238). The event is, in our chronology, the end of the third sub-phase, from the third decade of the century.

For this invasion see PETOLESCU 2010, 281-283.

${ }^{10}$ For which the most detailed presentation was made in Teodor 2006.
} 


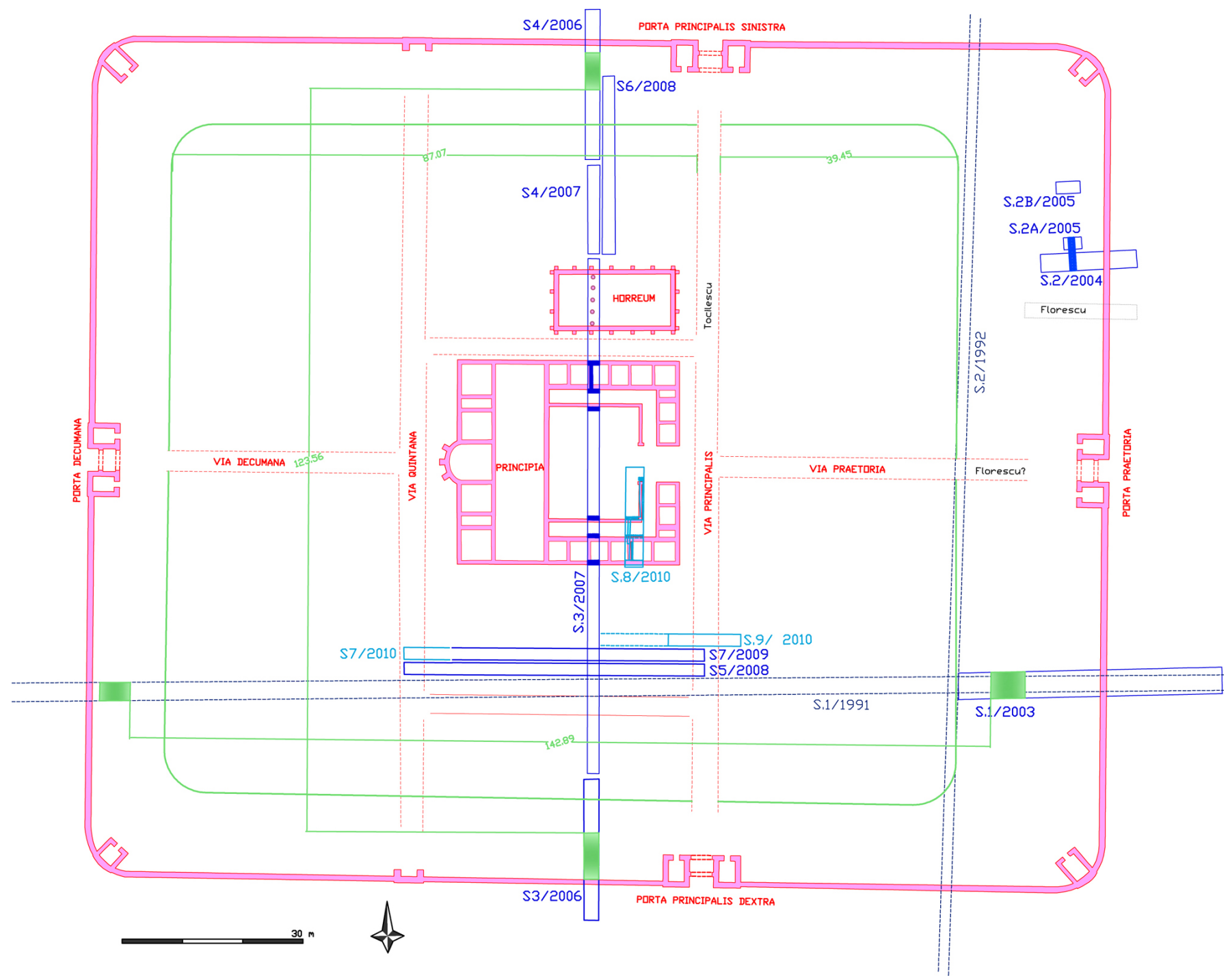

Fig. 1. Masterplan of the Răcari fort. Pink - stone buildings (phase 3); green - first earth and timber fort.

width, a necessary calculation when comes to establish from where the contexts of the first fort have to be expected, inside. The little fort has the length oriented east-west, as well as the later ones, measuring approx. $143 \mathrm{~m}$ inside ditches, and a width of $124.6 \mathrm{~m}$. Measured inside the presumptive line of the first palisade (levelled, not found), it is about 10-15 m shorter for each side (or about $130 \times 115 \mathrm{~m}$ ).

About that small fort details are just a few. Due to the relative asymmetry between first phase and the next, we had some uncertainties if the road structure of the early lay-out was followed or not by the next. In the summer campaign 2010 it was the first time to cut completely via principalis, in the trench noted S.9 (Fig. 1). On this occasion we have learned that the road is made of small river stones, as all the other roads in the camp, but only beginning with the second phase, being $4.3 \mathrm{~m}$ wide, with repairs or remade in the next phases. Below the second phase of the road there was a levelled clay layer and, next, a sandy layer on the base, matching the road as dimension, being just a bit larger $(4.6 \mathrm{~m}){ }^{11}$ The sand is currently used as infrastructure for high quality Roman roads, but never replaces the stone as

11 Let's note that both widths are meaningless in Roman feet, as $4.3 \mathrm{~m}$ is 13 feet and 4.6 is 14 feet. The most usual standards for a Roman military road are 6,12 or 18 feet. a cover for a road, and shouldn't be either the lowest layer of the foundation. The situation from via principalis is odd and should have a good explanation, as, for instance, the complete remade of the upper layers of the road.

The first camp from Răcari has been built, probably, by Legio V Macedonica, in the years of the wars raged by the emperor Trajan against Dacians (101-106), but this is not a fact above any doubt. The arguments used by Dumitru Tudor were the following: "The fort layout is similar with that from Drobeta, which implies that it was built in the time of Trajan or Hadrian, perhaps by detachments from Legio V Macedonica and those of numerus Mauretanorum E". ${ }^{12}$ The similitude of the plans of Drobeta and Răcari is irrelevant as long as the stone camp from Răcari (the only known by Tudor) was made in fact one century later than Drobeta. More, there could be no direct connection between Legio V Macedonica and numerus Maurorum $\Sigma$ (in a more likely restitution), no matter the third name, as we will see further. Worst, the brick attesting the presence of the legionaries from the fifth legion, found by Polonic and only described by Tocilescu, ${ }^{13}$ was lost long time ago. The stamp was broken, being read

${ }_{12}$ TUDOR 1965, 237, mine highlight on 'perhaps'

13 TOCILESCU in AEM, 19, 1896, 1, p.79, no. 4 = CIL III 14216; TUDOR 1965, 237. 
[legio] V M(acedonica), ${ }^{14}$ but on broken stamps there is not a long way from NM (numerus Maurorum) to VM, and the absence of the drawing or the photo is painful. Anyway, a vexillatio must have been there, as Grigore Florescu found another partial stamp, LEG [...]. ${ }^{15}$

Finally, we don't have reasons to deny that Legio $V$ Macedonica made the first camp in Răcari, although we cannot be fully confident. The headquarters of the legion was, previous to the Trajan's Wars, in Gigen (Oescus), on the right bank of Danube, facing Sucidava-Celei, therefore near the confluence of Jiu River in Danube. The legion joint the invasion task force as part of Moesia Inferior troops, acting in such distant places as Drobeta ${ }^{16}$ (73 km westward from Răcari) and Drajna (212 km eastward from Răcari). The legion was dispatched after the war (probably in 106 AD) near the last bent of Danube, in Dobruja, at TroesmisTurcoaia. ${ }^{17}$ Between Răcari and Turcoaia there are $370 \mathrm{~km}$ as the crow flies, and on the fastest way of communication in Antiquity, which is on water, there are over $500 \mathrm{~km}$, distance which excludes any further connection with its former war camp. The jurisdiction would be another problem for any supposed later link: probably eastern Oltenia (likely east of Jiu River) stood under the authority of Moesia Inferior in the final years of Trajan, ${ }^{18}$ but when Hadrian made the administrative reform it felt under the authority of Dacia Inferior. ${ }^{19}$ Therefore, Răcari and Troesmis were in different jurisdictions after $120 \mathrm{AD}$.

Concluding, it is pretty much possible that the first camp from Răcari was made by a vexillatio of the Fifth Macedonica, in the very beginning of the war led by Trajan against Decebalus. If it ever has been on the front line, as possible in $101 \mathrm{AD}$, or lately in $102,{ }^{20}$ then we have a motive for which via principalis was made (only?) by sand, and not by stone. In the hilly area east of the Răcari village one can find a soft kind of sandstone, not proper for building, used also in the following stages of evolution of the camp (mainly as emplecton), but in low quantities. There is no large or

\footnotetext{
${ }^{14}$ CIL III 14216, a-b = IDR II 167.

15 ILD 97. From Răcari comes also a fragmentary funerary inscription made by a member of legio XIII Gemina (IDR II 163).

16 DAVIDESCU 1980, 68, Fig. a), 84, Fig. b) for stamps LVM. The stamped bricks and tiles from Drobeta - the main head-bridge of the Imperial army - with the acronyms of the legio $V$ Macedonica - are from far the most numerous: no less than 159 (IDR II 99), all described as having the LVM stamp. Nevertheless, the stamps from ZAHARIADE/LICHIARDOPOL, 2006, 124, fig. 3 (three variants), for Drajna and Târgşor, with similar chronology, have the logo LEGVMAC. Other way, we have to consider that the stamp found by Florescu could come from other legion (as legio VI Claudia, IDR II 100, or legio XIII Gemina, IDR II 101). A stamp LVM, as known from Drobeta, was found also on the camp Bumbești (IDR II, 178), $74 \mathrm{~km}$ north of Răcari, but the legion was involved in building other major forts in southern Dacia, like Slăveni and Celei-Sucidava (VLĂDESCU 1983, 24), but that stamp, in all its length, is missing at Răcari.

17 The moment in which the Fifth Macedonica was removed from Oescus depends on the author (commentaries on APARASCHIVEI 2010, 80), between 102 and 107. Both opinions are right, because from 101 the legion was anymore in Oescus, but on different points of the combat line, and is not possible to know the official garrison in between.

18 VLĂDESCU 1983, 23-27; PROTASE 2001, 38-41; GUDEA/GĂZDAC 2007.

19 About the western limits of Dacia Inferior there are as many opinions as authors (e.g. PROTASE 2001, 39; BĂRBULESCU 2005, 16, map IV; BOGDAN CĂTĂNICIU 2007, 51; PETOLESCU 2010, 163, for the dispatch of the troops from Moesia Inferior, in the second war, which includes Legio V Macedonica). ${ }^{20}$ MATEI-POPESCU 2010, 47.
}

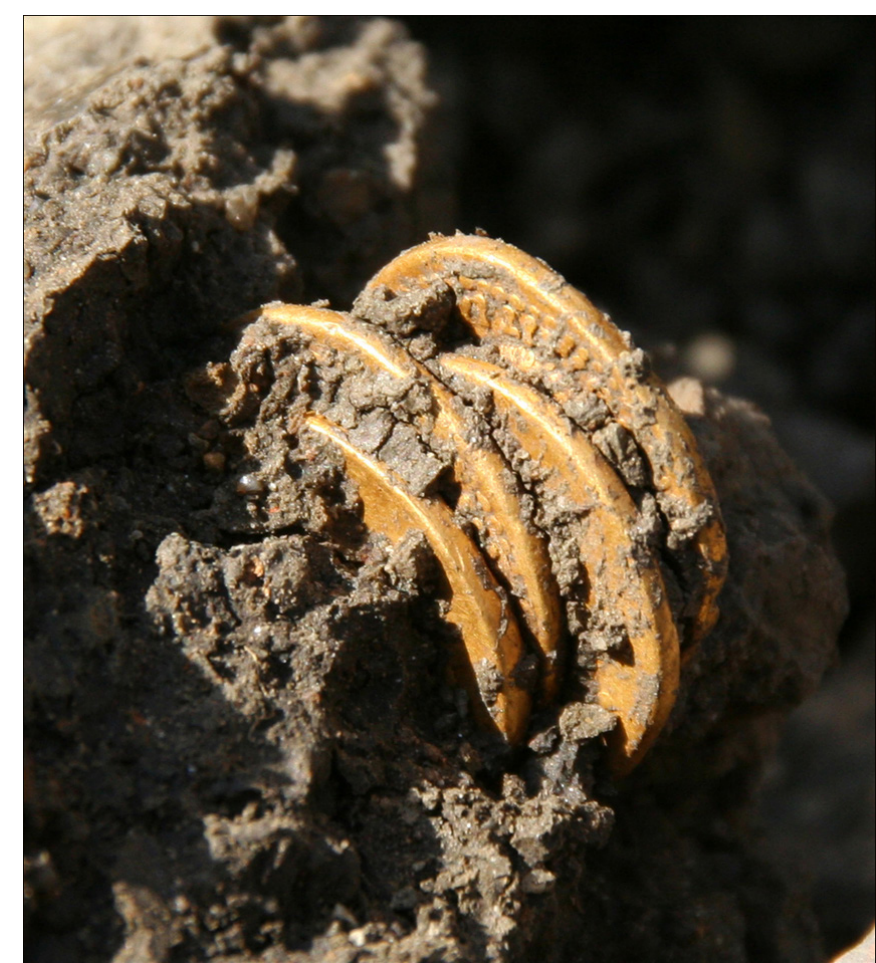

Fig. 2. The aurei deposit at the first sight.

small river stone in Jiu River, the stream being very slow (as expected in a ford). In order to find river stone, one has to travel about $50 \mathrm{~km}$ northward, but that way the enemy was located, at the beginning of the war. In the ford, for a change, there is plenty of sand.

The only other military unit attested in Răcari is a numerus Maurorum, the stamps on tiles being the single witness. The argument, older than half a century, if the last sign should be rendered $\Sigma$, as most of the Romanian scholars believe) or e (Grigore Florescu, Hadrian Daicoviciu, but some foreign historians too), ${ }^{21}$ is not solved, but does not have relevance here. Aiming to understand if in Răcari fort there is a time gap, or not, one has to discuss about the chronology of the military units named numeri, especially those of Moor origin, lots of them occurring in Dacia. ${ }^{22}$ Numeri were, at least in their beginnings, ethnic irregular units, commanded by officers of their own; such gentes (or natio) were, for instance, surii sagitarii, the builders of the forts from the Olt River Gorge, Arutela and Rădăcineşti, developed later in numerus Surorum sagittaria, known from inscriptions discovered in Romula. ${ }^{23}$ The Moorish mounted troops have gained a great deal of fame into the Dacian Wars, under the command of their own prince, Lucius Quietus; but they were not, yet, numeri; better - a natio. ${ }^{24}$ Anyway, after the dead of Trajan the leader felt in disgrace and has been killed, and his troops were sent back home. The reappearance of the Moors in Europe has to date after the Moorish Revolt (145 AD), restrained by Antoninus Pius. The Moors are coming

\footnotetext{
FLORESCU 1931, 19; TUDOR 1965, 234; SOUTHERN 1989, 93; IDR II, 168.

22 Forts with garrisons of Moors, others than Răcari: Jupa (Tibiscum, Caraş Severin County), Vețel (Micia, Hunedoara County), Zlatna (Ampelum, Alba County), Sutor (or Zutor, Optatiana, Sălaj County), Sânpaul (Mureş County), see NEMETH 2003, 446. See also NEMETH 1997, 103-105.

23 SOUTHERN 1989, 103-104; ŢENTEA 2012, 76.

${ }^{24}$ See the comprehensive study of SOUTHERN $(1989,82)$ for that distinction.
} 


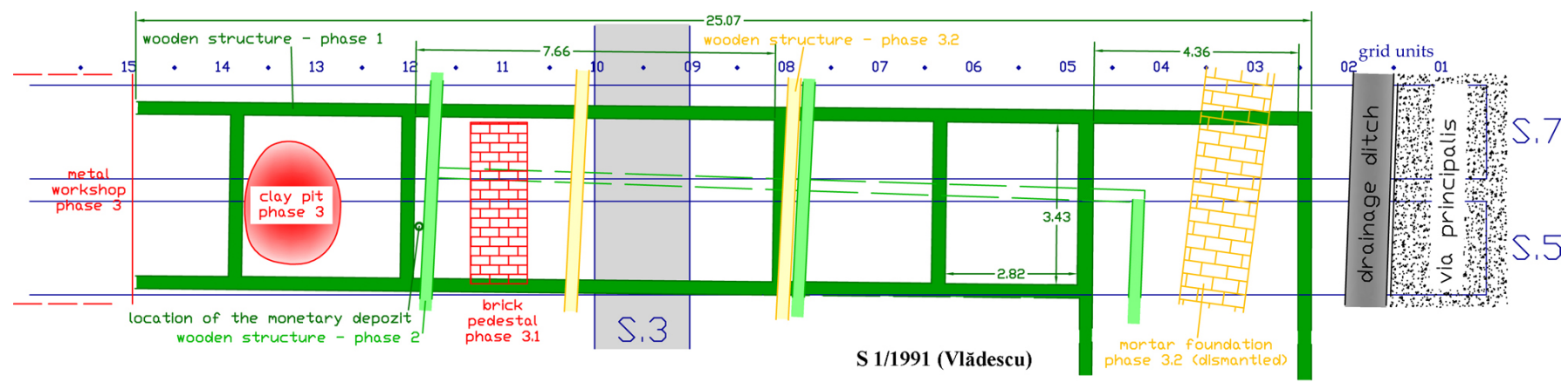

Fig. 3. Beam framed buildings in latus dextrum and the location of the monetary deposit.

back in Europe, either as former Roman allies, granted with the Roman citizenship by honesta missio, ${ }^{25}$ either as the defeated ones forced to fight, with no such privileges. These Moors occur in two diplomas emitted by Antoninus Pius, but the length of their services is not known, being most probably much shorter than the regular ${ }^{26}$ and we can at most presume that they were enlisted sometimes after 145 AD. Mauri gentiles took part to the Roman expeditions against the so-called Free Dacians, in $155-157 .{ }^{27}$ What is also positive knowledge is that Marcus Aurelius used Moors in the Marcomanic Wars, joining the vexillations from Ravenna and the fleet from Misenum, under the command of Valerius Maximianus. ${ }^{28}$ These pieces of information seem directly connected with the archaeological reports from Răcari, where, in two different stratigraphic instances have been stated that the large earth and timber fort was made probably at the end of the rule of Antoninus Pius, but possibly later.

A question stands... Did the evocatus institution work for the retired militaries from numeri, as suggested by the military diploma from IDR I 29? Apparently yes, if the beneficiaries were citizens. Secondly: what to do a veteran of the Moorish troops in a place where no military garrison was present, but no civil settlement also ${ }^{29}$ Was he re-enlisted in another military unit? Or he just followed his former unit far away, in another province $?^{30}$ Another fact is that diploma could be lost long time after $161 \mathrm{AD}$.

\section{PLACE AND CIRCUMSTANCES OF THE DISCOVERY}

In the summer 2008 it has been excavating in the trench named S.5, oriented East-West, placed north and next

\footnotetext{
${ }_{25}$ The military diploma found in Răcari (CIL XVI 114 = IDR I 29) was granted to a veteran from Moesia Superior, being issued under Antoninus Pius, after 145 but not later than 161 (the year is not known; see PETOLESCU 2002, 134135). We don't know yet when it was lost. The presence of a Moor veteran in Răcari should be connected with the establishment of the Moorish military unit, the discharged military probably following a relative (like a son, for instance).

26 SOUTHERN 1989, 105.

27 BENEA 1985, 142-143.

28 SOUTHERN 1989, 93.

29 There is no field research in the vicus, outside the ramparts. The settlement is quite extensive - about 40 hectares! - but probably younger than the large timber fort (phase 2). The reason is simple: if any civilian community would have lived the place, after 106, but before 160, it probably should have taken the former fortress in use, as so many times happened when the troops left a camp deserted. But there is no sign of such happenstance.

${ }^{30}$ For the chronology of the evolution from nationes to numeri, it is interesting the example of palmyrieni sagittari, defending Tibiscum as soon as $118 \mathrm{AD}$, but changing their name in numerus Palmyrenorum Tibiscensium in 159/160 (BENEA 2013, 194-195).
}

to the trench S.1/1991 made by Vlădescu, laying between via principalis and via quintana, $50 \mathrm{~m}$ long and $2 \mathrm{~m}$ wide. The main propose was to make clear the function of that area from latus dextrum, near principia. In the campaigns from 2009 and 2010 it have been dug successively the trenches S.7 and S.9, all $2 \mathrm{~m}$ wide, at intervals of $0.5 \mathrm{~m}$ (see the general plan from the Fig. 1). Aurei appeared in 2008, but will be profitable to use also the results of the following two years to decipher the plan of the building phases in the area.

Those four gold coins have been discovered in the unit grid no. 12, at $0.7 \mathrm{~m}$ deep, on the layer from which the edification begun in the phase 1 (the small fort). The spot is placed in a tinny strip between two foundation trenches of timber constructions from the phases 1 and 2 . The coins have been found in a tight contact, clearly suggesting a coin bag (Fig. 2). Considering the stratigraphic position, we can securely presume that the bag has been hidden below the floor made of wooden boards, against the western wall of the largest room of the first construction phase, 7.66 on $3.43 \mathrm{~m}$ (Figure 3). Nothing of the boards was preserved, as always on such a depth, in a soil which can be described as clayey, tough and dry.

About that timber building (Fig. 3) the research team made lots of hypotheses. On the layer where the building was made has been found nothing else but the coins, meaning that the facility was deserted organized, leaving nothing behind, except the hidden objects, of course. ${ }^{31}$ One hypothesis was made departing from the remark that the first room from east, near via principalis, was larger than the others in line, at least in depth; according that hypothesis, the facility could be a barrack if we accept that would be possible that we have missed a separation wall on the trench S.3, and if we could find the rest of two contubernia west of the metal workshop from the grids 15-18, a deep context which has cut all older layers. The length of the available space between via principalis and via quitana, over $45 \mathrm{~m}$, makes possible a barrack lying per scamna. Our efforts to find any trace of those contubernia, in the western part of the trench S.7, had no result, and the hypothesis has to be left away. There are many other objections, anyway, like the absence of the double row of rooms, papilio and arma.

The second hypothesis was that we have to turn back to the original idea, that latus dextrum should have the usual function of praetorium, at least for the first phase (but also very likely for the rest of them). We made a new analysis of

\footnotetext{
31 Such circumstances, not very spectacular as archaeology, are frequent for wood buildings not burned, the only visible traces being the foundation
} trenches themselves (HODGSON/BIDWELL 2004, 122). 
Table 1. The four aurei from the Răcari deposit ${ }^{32}$

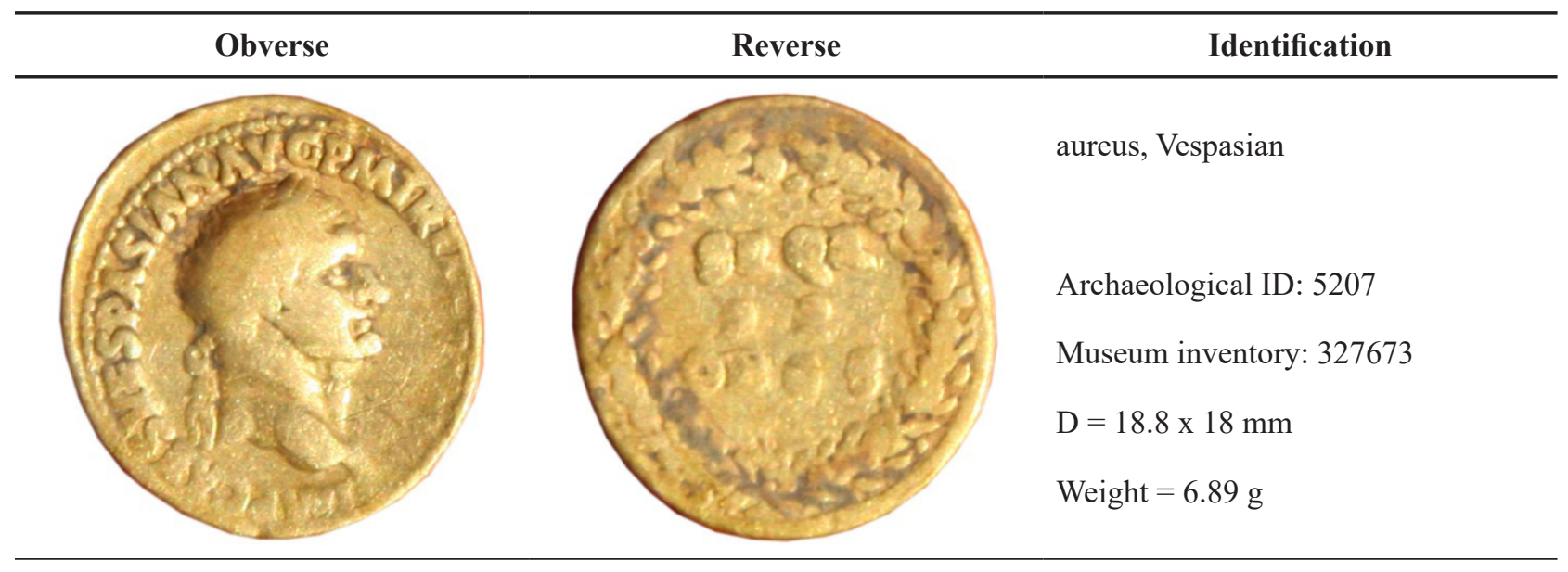

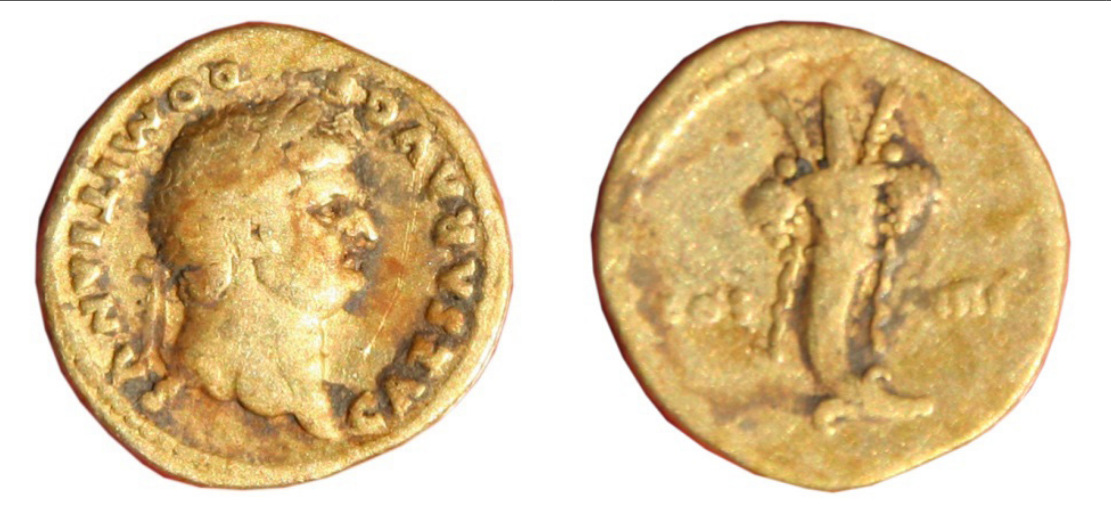

aureus, Vespasian for Domitian

Archaeological ID: 5209

Museum inventory: 327675

$\mathrm{D}=18.7 \times 19 \mathrm{~mm}$

Weight $=6.96 \mathrm{~g}$
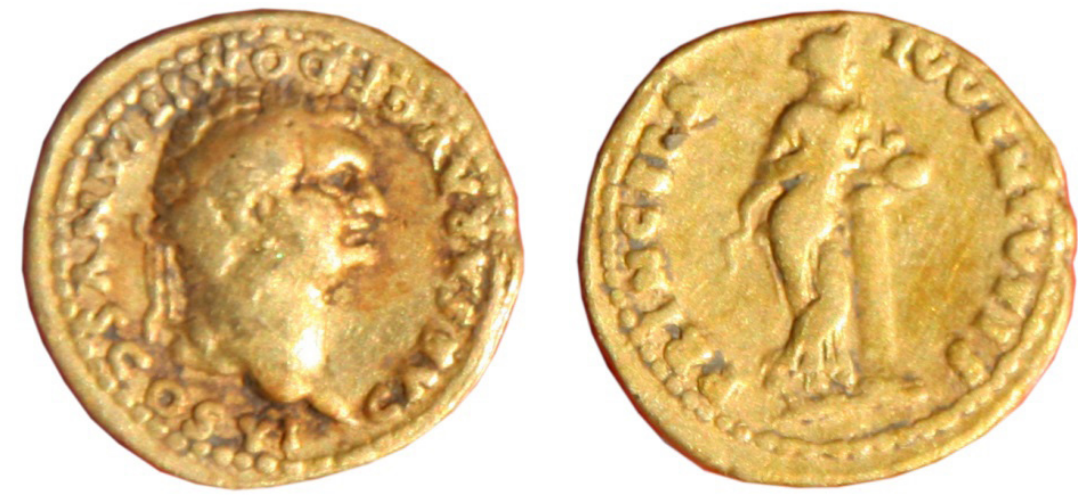

aureus, Vespasian for Domitian

Archaeological ID: 5208

Museum inventory: 327674

$\mathrm{D}=18 \times 18.5 \mathrm{~mm}$

Weight $=6.89 \mathrm{~g}$
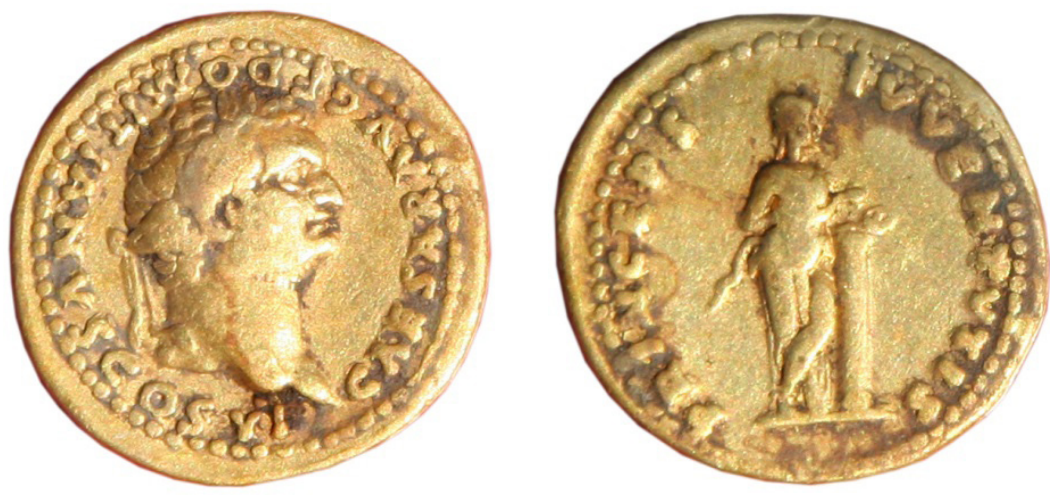

aureus, Vespasian for Domitian

Archaeological ID: 5210

Museum inventory: 327676

$\mathrm{D}=18.5 \times 19.2 \mathrm{~mm}$

Weight $=7.17 \mathrm{~g}$

the western profile of the trench S.3/2007 (which is crossing

${ }^{32}$ Photos taken on the site of discovery, after a superficial cleaning; the obverse of 5210 has a shadow on its up-right corner. Diameters taken from scaled photos (as they originally are). The weight was measured by the numismatist after the regular cleaning, in museum; note that the archaeologist was never able to touch again the artefacts after they reached museum. perpendicular S.5 and S.7), concluding that the sequence of the foundation boards from the recent excavation has a perfect match several meters southward, showing a pendant construction. $^{33}$ The two intervals between foundations

${ }_{33}$ All the older reports are available at http://www.esteo.ro/Racari/Index Rac.htm (see the report for 2007 and the Figure 2). The expected foundation 
have openings of $3.4 \mathrm{~m}$, suggesting two wings of the same building. The trenches of the foundations vary slightly in width around $0.3 \mathrm{~m}$, with depths between 0.4-0.5 m (from the oldest level). If so then we should have here a wooden building with the plan in U (if not rectangular), opened towards via quintana (?), with an atrium $10.6 \mathrm{~m}$ wide (including portico), and a pebbled alley on the median axis, $3 \mathrm{~m}$ wide. The pillars of the portico are not documented yet, but future diggings south of Vlădescu's trench could do it.

\section{THE FIND}

All the coins in that bag were gold coins with the nominal aureus, minted between 71-79, during Vespasian's rule. Three of them have Domitian's portrait, in his quality of Caesar and/or Consul. The last two, struck at the very end of Vespasian's rule, share one die, the obverse, ${ }^{34}$ suggesting that the money were never spend after distribution, as two of them are connected through fabrication. This is strongly suggesting that the coins were lost a relatively short time after their distribution. The hypothesis is strengthened by the fact that the artefacts have almost no wear marks, looking rather brand-new.

The weight of the coins is well below the standard of the age, although this is far from surprising, being rather a common practice. One fact yet is interesting, namely the consistent difference between the pair of the mints from 79 $\mathrm{AD}$, one of them being $4 \%$ lighter than the other, proving thus a great margin of error within the fabrication. As the wearing loss per year should be $0.00226 \mathrm{~g}$ or $0.00249 \mathrm{~g},{ }^{35}$ calculating with the average $(0.00237)$ comes out that the first of them was in circulation for 118 years before meeting the other one - its die brother -, just released to a soldier, before being both hidden and lost. Looking back at the pictures, such a difference is just impossible to be seen.

One reason to publish here the photos taken on the site, before a proper cleaning, is to prove that the scratches visible in some instances are not due to the conditions of discovery or a neglecting cleaning. The best example is given by the obverse image of the second coin in series, ID 5209, where one can see a long scratch in front of the portrait; that mark is covered, here and there, by reddish spots left by an organic matter (the leather of the pouch?) deposed on the surface and not fully removed. Such marks are many, as well as some bites, as a fully report of the numismatist could show, but they are not proving the wearing, but the usual testing of the quality of gold. Testing scratches are frequent and show only that the coin was circulated. ${ }^{36}$

marks, north of the older trench made by Cristian Vlădescu, are missing, and meaning only that we did not see them in 2007 . They are very difficult to catch, especially due to excessive toughness and dryness of the soil. In the next digging campaigns we have sprayed large quantities of water, in this area, in order to see something. Revisiting those drawings now (report for 2007, Figs. 2 and 3 ), we have noticed an interesting fact: although the layer corresponding to the first phase contains virtually no artefacts, it is quite thick; this is an indirect proof of the long time the site was deserted, between $106 \mathrm{AD}$ and (very likely) around 170.

34 I own this observation to Delia Moisil, of course. The matter is too important to be avoid.

35 An experiment noted by Delia Moisil in her unpublished study, sending to a large experiment made by Richard Duncan-Jones (DUNCAN-JONES 2006, 181).

${ }^{36}$ GĂZDAC 2017, 34, see the large picture with an aureus minted by Trajan,
Of course, professional numismatists could discuss the state of conservation better than I could do. What I can see is that the revers of the first issue (ID 5207) seems not very well preserved, or possibly not well minted. What is clear is the fact that the obvers was not struck vertically, the letters being deep and visible on the up-left, and almost lost on the lower part.

Such observations could drive us back to the hypothesis made by prof. C.C. Petolescu, and clearly I have to deal with.

Before closing this section dedicated to facts, I have to mention here that the four coins were tested with a portable XRF, giving average results over $99 \%$ gold, as they should be. ${ }^{37}$

\section{COMMENTARIES}

As I already said, the phases of the Roman fort at Răcari are published with details, in both Romanian and English ${ }^{38}$. Nevertheless, an esteemed historian and archaeologists published in 2010 a synthesis of the history of the first millennium after Christ, in which some could read about the sorrow adventure of Cornelius Fuscus (87 AD), a story were the name of the fort at Răcari is briefly mentioned (translation):

Another /secondary/ column would have been crossed Danube, progressing upstream Jiu River, intending to pass the mountains on the same place/Vâlcan Pass/. From this time could date the older phase (the timber one) of the Răcari fort, where three golden coins minted in the time of Vespasian were found. ${ }^{39}$

The note closing the paragraph (143) is drawn in the same fairy tale style, showing that the fourth mint from Vespasian would be a denarius... To be sure, C.C. Petolescu did not read my papers, because otherwise he would know that there are two timber phases, not one. Giving his life time experience in Roman military archaeology, he would have easily understood that his stand is impossible. I suppose...

I also have had troubles with my colleague numismatist, which asked me - about four times in a year - to tell why I am so sure that the first fort was not build earlier than Trajan. This is why I find myself compelled to explain things in a more explicit manner than intended.

There are several arguments to be considered. The first is the dimension of the earliest defensive ditch. The most common setup, even for very large marching camps, is with a ditch up to $2 \mathrm{~m}$ wide and $1 \mathrm{~m}$ deep. In Răcari case studied on all sides - the average dimensions are $6.6 \mathrm{~m}$ wide and $2 \mathrm{~m}$ deep. The surface of a section through the ditch is 1 square meter for the first case (or one cubic meter for each linear meter of the ditch), but 6.6 sq. $\mathrm{m}$ for the second case. That means at least seven times more effort to do it, something eligible if someone is planning to stay more than a week or a month.

A second fact is the kind of use for the inner space. Although we made some extensive diggings in the fort, most of it cannot be useful for this purpose: Trenches 1 and

full of scratches but not really circulated.

37 Only the first coin in the series is slightly below 99\%. Measurements provided by out colleague $\mathrm{Gh}$. Niculescu at the request of the numismatist (therefore the detailed results are left for the later).

38 TEODOR 2006 (Romanian, mainly for the phase 1, of direct interest here) and TEODOR 2009 (English).

${ }^{39}$ PETOLESCU 2010, 103-04, with the note 143. 
2 were drawn outside the earlier fort, and large parts from the middle area were already fully dug by our predecessors (principia and horreum) below the first phase's ground level. All what we really know is that on latus dextrum (or on the right part of the headquarters, as looking at porta praetoria) there is a wooden building in U shape, allegedly praetorium, or the commander house. The scheme fits, by itself, with a castrum stativum, more or less a permanent base of a military unit, and not a marching - or temporary - camp. ${ }^{40}$

There is no evidence for a temporary camp in the area, missing anything which might look like a tent peg, ${ }^{41}$ although we cannot rule out the hypothesis that the troops were housed in tents for a while, for the earlier phase. Saying that I am considering also a larger marching camp, fitting the military tradition before Trajan, ${ }^{42}$ when small precincts, around one hectare, were not habitually. There are available two sets of the Romanian orthophotos ${ }^{43}$ and another 7 or so on Google Earth $^{44}$ and none is suggesting a larger camp in the area.

A last set of arguments are coming from the historical conjecture. We do not know details about the campaign led by Fuscus, only the fact that it was short and catastrophic. In the next year (88) the Romans were already sending the revenger, Tettius Iulianus, acting far away, in Banat. ${ }^{45}$ Let me ask then the next: what to do an isolated cohort in the middle of a dangerous country, in the winter $87 / 88$ ? It doesn't make sense.

Of course, scholars may put a doubt on everything they want. But I was lucky. In August 2018, writing this paper, I found out that a similar gold coin - minted by Vespasian, brand-new looking - was just recovered from a systematic digging in the vicus near the fort at Războieni (Alba County, about the half way between Alba Iulia and Cluj-Napoca), in the oldest archaeological layer from the settlement, datable in the time of Trajan, after $106 \mathrm{AD} .{ }^{46}$ As aurei are strongly connected with military events and military units, ${ }^{47}$ but no Roman military action is known for central Transylvania before Trajan, one has to conclude that almost uncirculated coins of Vespasian could be lost some 30 years after their mint. How that was possible is beyond my qualification to tell.

I will conclude with just a few words about de gold deposit itself. Around the year $100 \mathrm{AD}$ the annual payment of an infantry man was about 1000 sesterti, or 250 denari, given in four yearly rates (named stipendia), both in silver or copper coins. As the exchange rate aureus-denarius was

\footnotetext{
40 The Trajan's Column shows "stone" camps, having always large tents in the middle, not timber buildings.

${ }^{41}$ Lots of artefacts are published (TUDOR 1965; BONDOC/GUDEA 2009, 237-273)

42 C.C. PETOLESCU $(2010,103)$ was supposing that the main column camp would be Schela Cladovei ( 650 x 567 m, or 37.44 ha), west of Drobeta., which is not sure, but proper.

${ }^{43}$ http://geoportal.ancpi.ro/geoportal/viewer/index.html, one for 2005 and another (much better) for 2010.

${ }^{44}$ Search for latitude $44.514008^{\circ}$, longitude $23.571962^{\circ}$

45 PETOLESCU 2010, 105.

${ }^{46}$ Personal communication Rada Varga, member of the excavation team, $18^{\text {th }}$ August 2018, on Messenger. For general information about the archaeological site see RUSU-BOLINDEȚ/ONOFREI 2010, especially 406 (the only military unit known for Războieni, ala I Batavorum milliaria, was brought in Dacia only under Hadrian's rule).

${ }_{47}$ As our unpublished study could prove.
}

$1: 25,{ }^{48}$ the four aurei found under the floor of praetorium mean less than half from a milites income, but more than one stipendium. Payments in gold for the Roman army were not the rule, but the exception, known as donativa, given for special events, like accession on power, and not as a salary, but as a supplement, buying the gratitude. Trajan's accession on power was only four years before the Dacian war, but the distribution could be older, as no newer coin than $79 \mathrm{AD}$ is present. I have to presume that aurei were important for militaries, as they have a great value on small packs, therefore they were not spent, but kept. Donativa were distributed only for the Praetorian guards and legionaries, which fits the hypothesis that the fort was made by a fraction of the legio VMacedonica.

Another irregular payment in gold was a travel allowance, named viaticum, but the documentary support is small and related only with the freshmen. ${ }^{49}$ As the military units from the Dacian front had losses and had to complete their numbers, this could be a possibility, but a freshman to perform duties in the commander's house is unlikely.

Interesting to note, the militaries were advised not to carry gold or silver coins when preparing for a battle, in order to avoid being hunted for money; ${ }^{50}$ this could be a reason to hide the money inside the fort. But why in praetorium? They could be hidden by the commander himself or by any other officer who had regular access in that space, because the small treasure was supposed to be recovered. It was not, and the owner never turned back.

This entire picture with the lost gold coins looks very much as a war time.

\section{REFERENCES}

\section{APARASCHIVEI 2010}

Aparaschivei, D., Oraşele romane de la Dunărea inferioară (secolele I-III p. Chr.) (Iaşi: Editura Universităţii Al. I. Cuza).

\section{BĂRBULESCU 2005}

Bărbulescu, M., Atlas-dicționar al Daciei romane (ClujNapoca: Tribuna).

\section{BENEA 1985}

Benea, D., Numerus Maurorum Tibiscensium. Contribuţii la istoria trupelor maure din Dacia, Banatica 8, 139-154.

BENEA 2013

Benea, D., Istoria Banatului în antichitate (Timișoara: Excelsior Art).

BOGDAN CĂTĂNICIU 2007

Bogdan Cătăniciu, I., Daci şi romani. Aculturaţie în Dacia (Cluj-Napoca: Centrul de Studii Transilvane).

BONDOC/GUDEA 2009

Bondoc, D./Gudea, N., Castrul roman de la Răcari. Încercare de monografie (Cluj-Napoca: Mega).

CIL

Corpus Inscriptionum Latinarum (Berlin: BerlinBrandenburgische Akademie der Wissenschaften, 1853-).

DAVIDESCU 1980

Davidescu, M., Drobeta în secolele I-VII e.n. (Craiova: Scrisul Românesc).

DUNCAN-JONES 2006

Duncan-Jones, R., Money and government in the Roman empire (Cambridge University Press) (first paperback edition 1998, digital printing 2006).

\footnotetext{
${ }^{48}$ SPEIDEL 2009, 351.

49 VAN HEESCH 2014, 140; SPEIDEL 2014, 57.

${ }^{50}$ VAN HEESH 2014, 150.
} 


\section{FLORESCU 1931}

Florescu, G., Castrul roman de la Răcari-Dolj. Săpăturile arheologice din 1928 şi 1930 (Craiova).

GĂZDAC 2017

Găzdac, C., Evidenţa numismatică de pe frontiera Daciei, Limes. Frontierele imperiului roman în România 2, 34-43.

GUDEA/GĂZDAC 2007

Gudea, N./Găzdac, C., Die Dakische Gebiete im der Römischer Provinz Moesia Inferior (101-118 n. Chr.), Ephemeris Napocensis 16-17 (2006-2007), 49-84.

HODGSON/BIDWELL 2004

Hodgson, N./Bidwell, P.T., Auxiliary Barracks in a New Light: Recent Discoveries on Hadrian's Wall, Britannia 35, 121-157.

IDR

Inscriptionum Daciae Romanae (București-Paris, 1975-)

ILD

Petolescu, C. C., Inscriptiile Latine din Dacia (Bucuresti: Editura Academiei Române, 2005).

ILS

Dessau, H., Inscriptiones Latinae Selectae (Berlin: BerlinBrandenburgische Akademie der Wissenschaften, 1892-).

MATEI-POPESCU 2010

Matei-Popescu, F., The Roman Army in Moesia Inferior (Bucharest: Conphys)

NEMETH 1997

Nemeth, E., Die Numeri in römischen Heer Dakiens, Ephemeris Napocensis 7, 101-116.

NEMETH 2003

Nemeth, E., Reflectarea unor grupuri etnice prin rit, ritual şi monumente funerare. Maurii. In: Bărbulescu, M. (ed.), Funeraria Dacoromana. Arheologia funerară a Daciei romane (Cluj-Napoca: Presa Universitară Clujeană), 447-449.

PETOLESCU 2002

Petolescu, C.C., Auxilia Daciae. Contribuţie la istoria militară a Daciei romane (Bucureşti: Ars Docendi).

PETOLESCU 2010

Petolescu, C.C., Dacia, un mileniu de istorie (Bucureşti: Editura Academiei Române).

PROTASE 2001

Protase, D., Dacia romană. In: Protase, D., Suceveanu, Al. (eds), Istoria românilor. II. Daco-romani, romanici, alogeni (București: Editura Enciclopedică), 35-54.

RUSU-BOLINDET/ONOFREI 2010

Rusu-Bolindeţ, V./Onofrei, C., Date noi privind activitatea militară şi cultura materială a alei I Batavorum de la Războieni-Cetate. In: Rusu-Bolindeț V., Sălăgean, T., Varga, R. (eds.), Studia Archaeologica et Historica. In honorem Magistri Dorin Alicu, 401-447.

SOUTHERN 1989

Southern, P., The Numeri of the Roman Imperial Army, Britannia 20, 81-140.

\section{SPEIDEL 2009}

Speidel, M.A., Roman Army Pay Scales. In: Speidel, M.A., Heer und Herrschaft im Römischen Reich der Hohen Kaiserzeit (Stuttgart: Franz Steiner Verlag), 349-380.

SPEIDEL 2014

Speidel, M.A., Roman army pay scales revisited: responses and answers. In: Reddé, M. (ed.), De l'ore pour les braves!: soldes, armées et circulation monétaire dans le mondes romain (Pessac: Ausonius Publications), 53-62.

TEODOR 2006

Teodor, E.S., Prima amenajare a castrului de la Răcari (jud. Dolj). In: Teodor, E.S., Ţentea, O. (eds.), Dacia Augusti Provincia, crearea provinciei, (Bucureşti: Cetatea de Scaun), 219-235.

TEODOR 2009

Teodor, E.S., Roman fort from Răcari (Dolj County, Romania) and its four stages. Plannimetry, stratigraphy and chronology. Field researches 2003-2006. In: Proceedings of the XX ${ }^{\text {th }}$ Congress of the Roman Frontiers, 4-11 Sept. 2006, Léon, Spain (Madrid: I.H. Hoffmeyer), vol. 2, 1524-1539.

TOCILESCU 1900

Tocilescu, G., Fouilles et recherches archaeologiques en Roumanie Inscriptions inédites (Bucharest: Impr. du «Corps didactique»).

TUDOR 1965

Tudor, D., Castra Daciae Inferioris VIII. Săpăturile lui Gr. Tocilescu în castrul roman de la Răcari (raionul Filiaşi, reg. Oltenia), Apulum 5, 233-257.

TUDOR 1978

Tudor, D., Oltenia romană (fourth ed.) (București: Editura Academiei Române).

ŢENTEA 2012

Tentea, O., Ex Oriente ad Danubium. The Syrian Units of the Danube Frontier of the Roman Empire, (București: Mega).

VLĂDESCU 1983

Vlădescu, C.M., Armata romană în Dacia Inferior (București: Editura militară).

VAN HEESCH 2014

van Heesch, J., Paying the Roman soldiers in the East ( $1^{\text {st }}$ $2^{\text {nd }}$ century AD). In: Reddé, M. (ed.), De l'ore pour les braves!: soldes, armées et circulation monétaire dans le mondes romain (Pessac: Ausonius Publications), 139-159.

ZAHARIADE/LICHIARDOPOL 2006

Zahariade, M./Lichiardopol, D., Componența şi structura armatei romane în nordul Munteniei, între 101-117, In: Teodor, E.S., Țentea, O. (eds.), Dacia Augusti Provincia, crearea provinciei (București: Cetatea de Scaun), 121-134. List of Illustrations 